\title{
In vitro evaluation of the tuberculocidal property of essential oils
}

\author{
S Dharan ${ }^{\text {** }, ~ G ~ R a j a s e k a r a m ², ~ P ~ K a n i a p p a n ², ~ P ~ H o l z n e r ~}{ }^{3}$, D Pittet $^{1}$ \\ From International Conference on Prevention \& Infection Control (ICPIC 2011) \\ Geneva, Switzerland. 29 June - 2 July 2011
}

\section{Introduction / objectives}

The re-emergence of tuberculosis on a global scale, together with the emergence and spread of Mycobacterium tuberculosis multidrug-resistant strains, is a worldwide public health problem that places a heavy burden on resource-poor countries. We investigated the antibacterial properties of certain essential oils against $M$. tuberculosis.

\section{Methods}

Laboratory tests were carried out in two phases. Phase I was conducted at the Sultanah Aminah Hospital, Malaysia, and phase II at the University of Geneva Hospitals. In phase I, $100 \mu \mathrm{l}$ of different essential oils were run down the middle of freshly inoculated L-J slants with $M$. tuberculosis to test for growth inhibition by direct contact with the oils. In phase II, we prepared two formulations from the essential oils showing tuberculocidal properties. Actively-growing M. tuberculosis cultures were exposed to aerosols with different concentrations of the formulations. After exposure of 5 min daily for 10 days, cultures were incubated for a further 10 days for visual observation of colony growth, followed by subcultures incubated for 6 weeks to evaluate the bactericidal effect.

\section{Results}

Phase I identified 3 oils with a cidal effect on direct contact. In phase II, we identified that a $20 \%$ mixture of essential oils in $30 \%$ ethanol was tuberculocidal. Subcultures showed no growth up to 3 weeks compared to controls, but showed growth of a few colonies at 6 weeks.

'Infection Control Programme, University of Geneva Hospitals, Geneva, Switzerland

Full list of author information is available at the end of the article

\section{Conclusions}

In vitro testing allowed to confirm that certain essential oils have tuberculocidal properties. Inhalation therapy with essential oils could be used as an adjunctive lowcost therapy to directly observed therapy and should be evaluated in controlled clinical trials.

\section{Disclosure of interest}

None declared.

\section{Author details}

${ }^{1}$ Infection Control Programme, University of Geneva Hospitals, Geneva, Switzerland. 'Dept of Microbiology, Hospital Sultanah Aminah, Johore Baru, Malaysia. ${ }^{3}$ Gold Princess, Geneva, Switzerland.

Published: 29 June 2011

doi:10.1186/1753-6561-5-S6-P42

Cite this article as: Dharan et al:: In vitro evaluation of the

tuberculocidal property of essential oils. BMC Proceedings 2011 5(Suppl 6):P42.
Submit your next manuscript to BioMed Central and take full advantage of:

- Convenient online submission

- Thorough peer review

- No space constraints or color figure charges

- Immediate publication on acceptance

- Inclusion in PubMed, CAS, Scopus and Google Scholar

- Research which is freely available for redistribution
C Biomed Central

\section{Biomed Central}

